\title{
APLIKASI PUPUK BIOURINE PADA BEBERAPA VARITAS KACANG HIJAU (Vigna radiata L) TERHADAP PRODUKSI KACANG HIJAU
}

\author{
Oleh : \\ NANANG DWI WAHYONO dan SRI RAHAYU *)
}

\begin{abstract}
ABSTRAK
Kacang hijau merupakan salah satu tanaman leguminosae yang cukup penting di Indonesia yang posisinya menduduki tempat ketiga setelah kedelai dan kacang tanah. Pemberian pupuk organik Biourine sebagai penyuplai unsur hara bagi tanaman adalah untuk mendukung pertumbuhan dan produksi beberapa varietas kacang hijau terhadap pemberian pupuk organik Biourine. Dalam penelitian ingin diketahui seberapa besar respon dan produksi kacang hijau yang diberi pupuk organik Biourine yang terbuat dari bahan dasar urine sapi. Penelitian ini dilakukan dengan menggunakan Rancangan Acak Kelompok (RAK) faktorial dengan dua faktor perlakuan. Masing-masing faktor terdiri dari 4 level dan 3 level, yang diulang sebanyak 3 kali. Perlakuan konsentrasi Pupuk Organik Cair Biourine menunjukkan pengaruh yang berbeda tidak nyata pada semua parameter yang diamati.Perlakuan varietas menunjukkan respon yang berbeda nyata terhadap parameter tinggi tanaman pada kacang hijau tidak bersertifikat (V1), jumlah cabang pada varietas Murai (V2), jumlah polong pada kacang hijau tidak bersertifikat (V1).Tidak terdapat interaksi antara konsentrasi (K) Pupuk Organik Cair Biourine dan Varietas (V) pada semua parameter.
\end{abstract}

Kata Kunci : Biourine, Kacang hijau

\section{BAB 1. PENDAHULUAN}

\subsection{Latar Belakang}

Kacang hijau merupakan salah satu tanaman leguminosae yang cukup penting di Indonesia yang posisinya menduduki tempat ketiga setelah kedelai dan kacang tanah.

Untuk masa tanam tahun ini, pada periode Januari hingga April 2010 produksi kacang hijau nasional diprediksi sebesar 77.000 ton, Mei hingga Agustus sebesar 127.000 ton dan September hingga Desember sebesar 131.000 ton (Hasniawati, 2010). Sejauh ini India merupakan produsen utama $(1,2$ juta ton dari 2,8 juta ha), diikuti oleh Thailand $(0,2$ juta ton dari 0,4 juta ha), dan Indonesia $(0,20$ juta ton dari 0,3 ha) (Somaatmadja, 1993).

Peran strategis lain dari kacang hijau komplementer dengan beras, sebab protein beras yang miskin lisin dapat diperkaya oleh kacang hijau yang kaya akan lisin. Implikasi dari sosialisasi konsumsi kacang hijau hingga mencapai $2,5 \mathrm{~kg} / \mathrm{tahun} / \mathrm{kapita}$, bila dikonversi untuk 225 juta penduduk, maka memerlukan tambahan produksi kacang hijau sebasar 200.000-215.000 ton. Tambahan produksi tersebut otomatis memerlukan tambahan areal tanam, yang berarti akan menampung tenaga kerja yang diperlukan untuk pengembangan lahan kering, (Deptan, 2008). Produksi kacang hijau selain sebagai sumber bahan pangan juga sangat baik untuk kesehatan manusia. Karena biji kacang hijau mengandung vitamin $\mathrm{B}$, yang berfungsi melancarkan peredaran darah, vitamin E sebagai antisterilisasi dan tidak menyebabkan kolesterol bagi yang mengkonsumsinya, karena lemak yang dikandungnya lemak tidak jenuh (Purwono dan Hartono, 2005).

Pemanfaatan penggunaan pupuk organik baik padat maupun cair adalah solusi yang tepat untuk mengurangi/meminimalisir penggunaan pupuk anorganik. Namun permasalahan pada pupuk organik adalah rendahnya unsur hara makro yang digunakan sebagai pupuk, hal ini berbeda dengan pupuk kimiawi hasil industri yang kandungan unsur hara makro $(\mathrm{N}, \mathrm{P}, \mathrm{K})$ memiliki kandungan tinggi.

Berdasarkan uraian diatas diperlukan alternatif lain yaitu dengan pemberian pupuk organik Biourine sebagai penyuplai unsur hara bagi tanaman untuk mendukung pertumbuhan dan produksi beberapa varietas kacang hijau terhadap pemberian pupuk organik Biourine. Oleh sebab itu peneliti ingin mengetahui seberapa besar respon dan produksi kacang hijau yang diberi pupuk organik Biourine yang terbuat dari bahan dasar urine sapi.

\subsection{Rumusan Masalah}

a. Seberapa jauh pengaruh aplikasi pupuk Biourine pada beberapa varietas kacang hijau terhadap produksi.

b. Varietas mana yang mempunyai produksi tinggi pada pemberian pupuk Biourine.

c. Apakah terjadi interaksi pemberian pupuk Biourine pada beberapa varietas kacang hijau terhadap produksi.

\subsection{Tujuan}


a. Mengetahui pengaruh pemberian pupuk Biourine terhadap peningkatan produksi pada beberapa varietas kacang hijau

b. Mengetahui varietas kacang hijau yang mempunyai produksi tinggi pada pemberian pupuk Biourine.

c. Mengetahui interaksi pemberian pupuk Biourine danbeberapa varietas kacang hijau terhadap produksi

\subsection{Manfaat}

Penelitian ini diharapkan memberikan manfaat bagi para petani untuk peningkatan produksi kacang hijau serta memberikan informasi tentang pupuk Biourine untuk meningkatkan produksi kacang hijau dan dapat diterapkan didalam melaksanakan budidaya tanaman kacang hijau.

\section{BAB 2. TINJAUAN PUSTAKA}

\subsection{Tanaman Kacang Hijau}

Kacang hijau merupakan tanaman legum yang cukup penting diIndonesia dan posisinya menduduki tempat ketiga setelah kedelai dan kacang tanah. Rukmana (2006) menyatakan bila dibandingkan dengan kacang-kacangan lain, kacang hijau memiliki kelebihan antara lain berumur genjah, lebih toleran terhadap kekeringan, dapat ditanam dilahan kurang subur dan sekaligus bisa sebagai penyubur tanah karena mampu bersimbiosis dengan bakteri rhizobium, budidaya mudah dan hama yang menyerang relatif sedikit. Namun demikian, produksi kacang hijau di Indonesia masih rendah dan belum mampu memenuhi kebutuhan domestik. Nurjen et al.(2002) menyatakan bahwa salah satu faktor penyebab rendahnya kacang hijau adalah pengendalian gulma yang belum tepat. Selain itu, budidaya kacang hijau masih dijadikan sebagai tanaman sampingan sehingga belum dilakukan teknik budidaya yang optimal (Supeno danSujudi, 2004).

Tingkat produktivitas sangat dipengaruhi oleh banyak factor antara lain penggunaan varietas unggul, kesuburan tanah serta teknik budidaya.

Hingga saat ini, pemerintah telah melepas 20 varietas kacang hijau, dan 19 varietas di antaranya dihasilkan oleh Badan Litbang Pertanian. Kacang hijau yang umur panennya hanya 55 hari, menjanjikan dikembangkan di daerah dengan irigasi maupun curah hujan terbatas. Di pantai Utara Jateng, kacang hijau menjadi andalan ekonomi petani khususnya pada musim kemarau kedua seperti saat ini, ketika tanaman lain berisiko besar jika dibudidayakan.

Ternyata di Caruban hingga ke Pilangkenceng Kab Madiun, kacang hijau juga menjadi tanaman potensial penambah pendapatan petani. Sekali lagi jika air terbatas, maka budidaya kacang hijau menjadi harapan petani. Varietas Walet, yang merupakan hasil seleksi galur introduksi dari AVRDC Taiwan, dilepas tahun 1985. Varietas kacang hijau terbaru adalah Vima 1 dilepas 2008. Sedangkan varietas Sriti mempunyai diskripsi sebagai berikut : Umur genjah dan harga jual tinggi, menjadi daya tarik petani untuk menanam kacang hijau. Di Pantura Jateng, harga kacang hijau pernah mencapai Rp 12.500/kg. Dilepas pada tahun : 1992, asal : hasil seleksi galur dari varietas introduksi asal AVRDC Taiwan, hasil rata-rata : 1,58 t/ha biji kering, warna hipokotil : hijau, warna epikotil : hijau, warna batang : hijau, warna biji : hijau kusam, warna polong tua : hitam, bentuk tanaman : tegak, tinggi tanaman: $40-60 \mathrm{~cm}$, umur $50 \%$ berbunga : 35 hari, umur polong masak : 60-65 hari, bobot 1000 biji : 60-65 g, kadar protein : 19,5\%, kadar lemak : 1,0\%, karbohidrat : 66,0\%, katahanan terhadap penyakit : toleran penyakit bercak daun (Cercospora sp.), toleran penyakit embun tepung, sifat lain : letak polong di atas mahkota daun, polong masak serempak, keterangan : beradaptasi baik pada keadaan kering.

\subsection{Pupuk Organik Biourine}

Biourine dari urine sapi memberikan pengaruh positif terhadap pertumbuhan vegetative tanaman (Anty, 1980 dalam Mardalena, 2007). Penggunaan pupuk cair Biourine standarnya adalah 5-10 cc untuk tanaman hortikultura.

Berdasarkan hasil analisa kandungan biourine, yaitu sebagai berikut:

Tabel 2.1 Kandungan Biourine

\begin{tabular}{ccccc}
\hline No. & \multicolumn{3}{c}{ Kandungan unsur hara } \\
\cline { 2 - 5 } 1. & \multicolumn{2}{c}{ Makro } & \multicolumn{2}{c}{ Mikro } \\
Kadar N & $3,19 \%$ & $\mathrm{Fe}$ & 2076 \\
2. & Kodal) & & & $\mathrm{ppm}$ \\
& & & $\mathrm{Cu}$ & 5,93 \\
3. & Kadar $\mathrm{K} 2 \mathrm{O}$ & $1,9 \%$ & $\mathrm{Zn}$ & $\mathrm{ppm}$ \\
& & & & $\mathrm{ppm}$ \\
4. & Kadar $\mathrm{CaO}$ & $2,47 \%$ & $\mathrm{Mn}$ & 7,45 \\
& & & & $\mathrm{ppm}$ \\
5. & Kadar $\mathrm{MgO}$ & $1,5 \%$ & $\mathrm{pH}$ & 6,87 \\
6. & Kadar Na & $0,99 \%$ & $\mathrm{ZPT} / \mathrm{IAA}$ & 154 \\
& & & & $\mathrm{ppm}$ \\
\hline
\end{tabular}

Sumber: Analisa Laboratorium (Lab.) Tanah

Politeknik Negeri Jember. Nomor: 01/lab.

Tanah/V/2009 (2009).

TDP: $\quad$ 130655214144, SIUP Lestari, 503.510/588/429.310/2008 menyatakan bahwa manfaat Biourine, yaitu:

mempercepat pertumbuhan tanaman, merangsang pertumbuhan akar, batang, daun, bunga, dan buah, 
dapat digunakan untuk memupuk tanaman padi, palawija, Lombok/cabe, sayur-sayuran, dan buahbuahan tanaman tahunan dan tanaman hias/bunga, dapat meningkatkan hasil produksi, dapat memperbaiki kesuburan tanah dan ramah terhadap lingkungan.

\subsection{Hipotesis}

H0 : Konsentrasi pemberian pupuk Biourine tidak berpengaruh terhadap produksi pada beberapa varietas kacang hijau.

H1 : Konsentrasi pemberian pupuk Biourine berpengaruh terhadap produksi pada beberapa varietas kacang hijau.

HO : Varietas kacang hijau tidak berpengaruh terhadap pemberian pupuk Biourine pada produksi.

H1 : Varietas kacang hijau berpengaruh terhadap pemberian pupuk Biourine pada produksi.

H0 : Tidak terdapat interaksi antara pemberian pupuk Biourine dan beberapa Varietas kacang hijau terhadap produksi.

H1 : Terdapat interaksi antara pemberian pupuk Biourine dan beberapa Varietas kacang hijau terhadap produksi.

\section{BAB 3. METODOLOGI}

\subsection{Tempat dan Waktu Penelitian}

Penelitian dilaksanakan di Politeknik Negeri Jember pada Bulan September 2012 sampai dengan Bulan Desember 2012, dengan ketinggian tempat $89 \mathrm{~m}$ di atas permukaan laut dengan jenis tanah regosol/entisol.

\subsection{Alat dan Bahan}

Alat yang digunakan dalam penelitian ini adalah : cangkul, kored, hand sprayer, meteran, tugal, ember, tali raffia dan alat-alat tulis.

Bahan yang dibutuhkan dalam penelitian ini adalah : Benih kacang hijau pasar, Benih kacang hijau varietas Walet, Benih kacang hijau varietas Sriti, pupuk Biourine, pupuk Urea, pupuk $\mathrm{KCl}$, pupuk SP-36, pestisida, air, lahan

\subsection{Metode Penelitian}

Penelitian ini dilakukan dengan menggunakan Rancangan Acak Kelompok (RAK) faktorial dengan dua faktor perlakuan. Masingmasing faktor terdiri dari 4 level dan 3 level, yang diulang sebanyak 3 kali. Masing-masing perlakuan adalah sebagai berikut:

a. Faktor Pertama yaitu $\mathrm{K}=$ Konsentrasi Pupuk Biourine yang terdiri dari:

$\mathrm{K}_{0}$ : Tanpa pupuk Biourine (0\%)

$\mathrm{K}_{1}$ : Pupuk Biourine $10 \%$

$\mathrm{K}_{2}$ : Pupuk Biourine $15 \%$

$\mathrm{K}_{3}$ : Pupuk Biourine $20 \%$

b. Faktor Kedua yaitu V= Varietas kacang hijau yang terdiri dari:
$\mathrm{V}_{1}$ : Kacang hijau pasar

$\mathrm{V}_{2}$ : Kacang hijau Walet

$\mathrm{V}_{3}$ : Kacang hijau Sriti

Sehingga diperoleh 12 kombinasi perlakuan yang masing-masing diulang 3 kali, sehingga terdapat 36 plot. Satu perlakuan dalam satu plot terdiri dari 9 tanaman. Sehingga terdapat $36 \times 9=324$ tanaman percobaan.

\subsection{Pelaksanaan Penelitian}

a. Persiapan Lahan

Pengolahan tanah dilakukan secara manual yaitu dengan cara dicangkul.

b. Pembuatan Bedengan

Areal pertanaman yang akan digunakan di buat bedengan atau dibuat plot percobaan dengan ukuran $120 \mathrm{~cm}$ x $60 \mathrm{~cm}$ per plot, jumlah plot untuk 3 ulangan sebanyak 36 plot. Jarak antar plot $50 \mathrm{~cm}$ dan jarak antar ulangan $75 \mathrm{~cm}$.

c. Penanaman

Penanaman dilakukan dengan cara memasukkan 2 benih kacang hijau setiap lubang tanam dengan kedalaman $2 \mathrm{~cm}$ dari permukaan tanah dengan jarak tanam $40 \times 20 \mathrm{~cm}$.

d. Perlakuan Pemupukan

Aplikasi Biourine diberikan pada tanaman berumur 7 hari setelah tanam (1 minggu), 21 hari setelah tanam (3 minggu), 35 hari setelah tanam (5 minggu), 49 hari setelah tanam (7 minggu), dengan konsentrasi yang telah ditentukan pada setiap perlakuan.

e. Pemeliharaan

Penyiraman : dilakukan sesuai dengan kondisi lapang

Pemupukan : Pupuk dasar diberikan tiga hari sebelum dilakukan penanaman kacang hijau yaitu dengan menggunakan pupuk Urea $45 \mathrm{~kg} / \mathrm{ha}, \mathrm{SP}-3645-90 \mathrm{~kg} / \mathrm{ha}$, dan $\mathrm{KCl} 50 \mathrm{~kg} / \mathrm{ha}$.

Penyiangan : Penyiangan dilakukan jika memang diperlukan.

Pengendalian Hama dan Penyakit : Pengendalian hama dapat dilakukan dengan insektisida seperti Confidor dan Curacron dengan dosis 2-3 ml/liter air dan volume semprot 500-600 liter/ha. Sedangkan untuk pengendalian penyakit dapat dilakukan dengan Dithane M-45 pada awal serangan dengan dosis $2 \mathrm{gr} / \mathrm{l}$ air. Penyakit embun tepung dikendalikan efektif dengan fungisida Hexakonazol yang diberikan pada umur 4 dan 6 minggu.

f. Panen dan Pasca Panen 
Panen dilakukan pada saat polong tiap tanaman sudah kering dan berwarna coklat atau hitam dengan caran dipetik. Polong segera dijemur selama 2-3 hari hingga kulit mudah terbuka, kemudian dilakukan pemisahan biji dari polongnya.

\subsection{Parameter Pengamatan}

Teknik pengambilan data dilakukan dengan menggunakan sampel, dimana setiap plot diambil 3 sampel. Adapun parameter yang diamati dalam kegiatan penelitian ini adalah sebagai berikut:

a. Tinggi Tanaman $(\mathrm{cm})$

Tinggi tanaman diukur mulai dari pangkal batang diatas permukaaan tanah.dilakukan setiap minggu dimulai dari 2 minggu setelah tanam sampai 8 minggu setelah tanam.

b. Produksi Biji Per Tanaman (gram)

Dilakukan setelah kacang hijau dijemur selama 2-3 hari, kemudian biji dipisahkan dari polongnya lalu ditimbang per tanaman sampel.

c. Berat per 100 biji

Diambil biji dari setiap plot secara acak sebanyak 100 biji kemudian ditimbang.

\section{BAB 4. HASIL DAN PEMBAHASAN}

\subsection{Hasil}

Hasil penelitian Aplikasi Pupuk Biourine pada Beberapa Varietas Kacang Hijau (Vigna radiata L.) Terhadap Produksi Kacang Hijau yang telah dilaksanakan diperoleh hasil pengamatan dari parameter pengamatan tinggi tanaman, produksi biji per tanaman sampel (gram), dan produksi biji per 100 biji diperolah hasil sebagai berikut:

a. Tinggi Tanaman

Pengamatan tinggi tanaman dilakukan pada umur 42 hari setelah tanam. Hasil pengamatan menunjukan nilai rata-rata yang berbeda pada perlakuan varietas, sedangkan perlakuan konsentrasi pupuk Biourine tidak menunjukan nilai yang berbeda. Sidik ragam pada pengamatan parameter tinggi tanaman disajikan pada Tabel 4.1.

Tabel 4.1 Sidik Ragam Pengamatan Tinggi Tanaman

\begin{tabular}{|c|c|c|c|c|}
\hline \multicolumn{5}{|c|}{ Umur 42 hst } \\
\hline SK & $\mathrm{db}$ & F.Hit & \multicolumn{2}{|c|}{ F.Tabel } \\
\hline & & & $5 \%$ & $1 \%$ \\
\hline $\mathrm{Ul}$ & 2 & & & \\
\hline $\mathrm{P}$ & 11 & & & \\
\hline $\mathrm{V}$ & 2 & $3,62 *$ & 3,44 & 5,72 \\
\hline $\mathrm{K}$ & 3 & $0,36^{\mathrm{ns}}$ & 3,50 & 4,82 \\
\hline
\end{tabular}

\begin{tabular}{lllll} 
V x K & 6 & $1,02^{\text {ns }}$ & 2,55 & 3,76 \\
Galat & 22 & & & \\
\hline Total & 35 & & & \\
\hline
\end{tabular}

Keterangan :

ns : berbeda tidak nyata

* : berbeda nyata

** : sangat berbeda nyata

Pada Table 4.1 diatas menunjukan bahwa pada perlakuan varietas untuk pengamatan tinggi tanaman menunjukkan berbeda nyata pada umur 42 hst, sedangkan perlakuan konsentrasi dan interaksi tidak menunjukkan nilai yang berbeda nyata (non significan). Hasil perhitungan uji lanjut BNT 5\% untuk perlakuan varietas dapat dilihat pada Tabel 4.2

Tabel 4.2 Uji Lanjut BNT 5\% Pada Parameter Tinggi Tanaman Umur 42 Hst

\begin{tabular}{lcc}
\hline Perlakuan & 42 hst & Notasi \\
\hline V1 & 45,58 & a \\
V2 & 40,30 & b \\
V3 & 40,74 & ab
\end{tabular}

BNT 5\% $\quad 4,88$

Keterangan : Angka yang diikuti dengan huruf yang sama pada kolom yang sama menunjukan berbeda tidak nyata.

b. Produksi Biji per Tanaman ( 3 Tanaman)

Pengamatan produksi biji per tanaman dilakukan setelah polong kacang hijau dikeringkan kemudian biji dipisahkan dari polongnya lalu dilakukan penimbangan setiap 3 tanaman sampelnya. Hasil perhitungan sidik ragam untuk pengamatan produksi biji per tanaman sampel disajikan pada Tabel 4.3 berikut.

Tabel 4.3 Sidik Ragam Pengamatan Produksi Biji per Tanaman

\begin{tabular}{|c|c|c|c|c|c|c|}
\hline \multirow[b]{2}{*}{ SK } & \multirow{2}{*}{$\begin{array}{l}d \\
b\end{array}$} & \multirow[b]{2}{*}{$\mathrm{JK}$} & \multirow[b]{2}{*}{ KT } & \multirow{2}{*}{$\begin{array}{l}\mathrm{F} \\
\text { Hitung }\end{array}$} & \multicolumn{2}{|c|}{ F Tabel } \\
\hline & & & & & $5 \%$ & $\begin{array}{l}1 \\
\%\end{array}$ \\
\hline & & & 13 , & & & \\
\hline Ulangan & 2 & 26,72 & 36 & & & \\
\hline Perlaku & 1 & 366,4 & 33 , & & & \\
\hline an & 1 & 2 & 31 & & & \\
\hline & & 144,2 & 72 , & & 3,4 & 5 , \\
\hline V & 2 & 3 & 11 & $2,61^{\mathrm{ns}}$ & 4 & 72 \\
\hline & & & 17 , & & 3,0 & 4 \\
\hline K & 3 & 52,69 & 56 & $0,56^{\mathrm{ns}}$ & 5 & 82 \\
\hline & & 169,5 & 28 , & & 2,5 & 3 , \\
\hline VxK & 6 & 0 & 25 & $1,04^{\mathrm{ns}}$ & 5 & 76 \\
\hline
\end{tabular}




\begin{tabular}{lrrr} 
& 2 & 585,1 & 26, \\
Galat & 2 & 9 & 60 \\
\hline \multirow{3}{*}{ Total } & 3 & 978,3 & \\
\hline
\end{tabular}

Keterangan :

ns : berbeda tidak nyata

* : berbeda nyata

** : sangat berbeda nyata

Pada Tabel 4.3 diatas menunjukkan nilai

F Hitung yang berbeda tidak nyata (non significan) untuk semua perlakuan, sehingga pada pengamatan prpoduksi biji per tanaman tidak dilakukan uji lanjut BNT.

\section{c. Berat 100 Butir Biji}

Pengamatan Berat 100 butir biji dihitung setelah biji dikeringkan pada saat pasca panen, kemudian dihitung dan ditimbang. Hasil perhitungan kemudian dianalisis menggunakan sidik ragam. Hasil perhitungan sidik ragam disajikan pada Tabel 4.4 berikut.

Tabel 4.4 Sidik Ragam Pengamatan Berat 100 Butir Biji

\begin{tabular}{|c|c|c|c|c|c|c|}
\hline \multirow{2}{*}{ SK } & \multirow{2}{*}{$\begin{array}{l}\mathrm{d} \\
\mathrm{b}\end{array}$} & \multirow{2}{*}{$\mathrm{JK}$} & \multirow{2}{*}{ KT } & \multirow{2}{*}{$\begin{array}{l}\mathrm{F} \\
\text { Hitun } \\
\mathrm{g}\end{array}$} & \multicolumn{2}{|c|}{ F Tabel } \\
\hline & & & & & $5 \%$ & $1 \%$ \\
\hline & & 1,3 & & & & \\
\hline Ulangan & 2 & 3 & 0,67 & & & \\
\hline Perlaku & 1 & 1,8 & & & & \\
\hline \multirow[t]{2}{*}{ an } & 1 & 1 & 0,16 & & & \\
\hline & & 0,2 & & 0,68 & 3,4 & \\
\hline \multirow[t]{2}{*}{ V } & 2 & 6 & 0,13 & ns & 4 & 5,72 \\
\hline & & 0,4 & & 0,88 & 3,0 & \\
\hline \multirow[t]{2}{*}{$\mathrm{K}$} & 3 & 9 & 0,16 & ns & 5 & 4,82 \\
\hline & & 1,0 & & 1,04 & 2,5 & \\
\hline \multirow[t]{2}{*}{$\mathrm{VxK}$} & 6 & 5 & 0,18 & ns & 5 & 3,76 \\
\hline & 2 & 3,6 & & & & \\
\hline \multirow[t]{2}{*}{ Galat } & 2 & 7 & 0,17 & & & \\
\hline & 3 & 6,8 & & & & \\
\hline Total & 5 & 1 & & & & \\
\hline
\end{tabular}

Keterangan :

ns : berbeda tidak nyata

* : berbeda nyata

** : sangat berbeda nyata

Pada Tabel 4.4 diatas pengamatan berat 100 butir biji menunjukkan nilai $\mathrm{F}$ hitung yang berbeda tidak nyata (non significan) untuk semua perlakuan, sehingga pada pengamatan ini tidak dilakukan uji lanjut BNT.

\subsection{Pembahasan}

a. Tinggi Tanaman

Pemberian pupuk Biourine dengan konsentrasi yang berbeda ternyata tidak berpengaruh terhadap parameter tinggi tanaman. Hal ini menunjukan bahwa meskipun konsentrasi Biourine yang diberikan berbeda, tanaman tetap dapat melakukan proses metabolisme secara optimal dengan asupan hara yang ada didalam tanah, sehingga mampu memenuhi pada fase vegetatif yang cenderung masih rendah. Pertumbuhan tinggi tanaman dan perkembangan tanaman juga dipengaruhi oleh sifat genetik dan kemampuan tanaman dalam beradaptasi dengan kondisi lingkungan tempat hidupnya.Selain itu kondisi lingkungan pada saat itu sering terjadi hujan sehingga sangat tidak mendukung untuk penyerapan pupuk Biourine pada tanaman. Disamping itu juga unsur $\mathrm{N}$ yang ada dalam Biourine dapat menguap ke udara dan kandungan $\mathrm{N}$ yang rendah.

Sedangkan perlakuan Varietas menunjukan perbedaan yang nyata pada masingmasing varietas dimana varietas kacang hijau Sriti pertumbuhan tinggi tanaman lebih bagus dibanding varietas yang diperoleh dari pasar. Hal ini disebabkan benih varietas Sriti ukurannya lebih besar. Benih merupakan faktor penentu didalam pertumbuhan. Hal ini diperkuat dengan pendapat Sutopo (1993), bahwa benih berukuran besar mempunyai cadangan makanan yang lebih banyak dari pada benih berukuran kecil, terutama kandungan proteinnya. Dalam jaringan penyimpanan benih memiliki karbohidrat, protein dan lemak serta mineral yang dibutuhkan sebagai bahan baku dan energi embrio pada saat perkecambahan.

Selain itu Hakim (2009) menyatakan bahwa Nitrogen merupakan penyusun protein dan protein merupakan penyusun utama protoplasma yang berfungsi sebagai pusat proses metabolisme dalam tanaman yang selanjutnya akan memecau pembelahan dan pemanjangan sel tanaman.

\section{b. Produksi Biji per Tanaman}

Hasil produksi biji per tanaman dengan pemberian pupuk Biourine menunjukan perbedaan yang tidak nyata. Diduga pengaruh kandungan unsur hara Biourine yang diterima oleh tanaman memberikan pertumbuhan secara optimal. Biourine merupakan pupuk daun yang dapat diberikan pada tanaman melalui daun (stomata) dan memiliki kandunganhara yang dibutuhkan oleh tanaman.Penggunaan pupuk daun dapat memberikan hara sesuai kebutuhan tanaman. Hara yang dibutuhkan tanaman memang relatif sedikit 
tetapi bersifat kontinyu (Lingga dan Marsono, 2013). Oleh karena itu pupuk daun diberikan lebih sering tetapi dosisnya atau konsentrasinya tidak terlalu tinggi. Selain itu produksi biji per tanaman yang tidak berbeda nyata dengan pemberian Biourine ini diduga kurangnya asupan hara $\mathrm{P}$ dan $\mathrm{K}$ yang tersedia di dalam tanah dan aplikasi Biourine belum mencukupi kebutuhan tanaman tersebut.

Banyaknya jumlah biji dipengaruhi oleh faktor pembungaan dan lingkungan yang mendukung pada saat pengisian polong.Hal in sesuai dengan pendapat Somaatmadja (1993) yang menyatakan bahwa banyaknya polong dan biji/polong terbentuk ditentukan oleh faktor pembungaan dan lingkungan yang mendukung saat pengisian polong.

\section{c. Berat 100 Biji}

Pemberian pupuk Biourine terhadap beberapa varietas kacang hijau pada parameter berta per 100 biji, menunjukan perbedaan yang tidak nyata. Hal ini disebabkan oleh kondisi lingkungan yang berebeda dan berkurangnya jumlah polong/tangkai atau biji/polong setiap tanaman menyebabkan kompetisi hasil fotosintesis untuk ke setiap polong pada setiap tanaman lebih sedikit, selain itu juga faktor cuaca yang kurangnya sinar matahari yang tidak mendukung tanaman kacang hiajiu dalam proses produksi. Pengaruh pupuk Biourine tidak berpengaruh banyak karena kandungan unsur Nitrogen dalam pupuk Biourine yang rendah hanya $2 \mathrm{mg}$ dibanding dengan pupuk urea.Penentuan Berat 100 bij dapat dipergunakan untuk mengetahui jumlah benih per kg dari suatu benih yang dapat dijadikan standar dalam perencanan kebutuhan benih untuk persemaian maupun penanaman.Bobot 100 butir benih yang dihasilkan lebih suatu jenis tanaman atau varietas. Dengan mengetahui biji yang besar atau berat berarti menandakan biji tersebut pada saat dipanen sudah benar-benar dalam keadaan masak, karena biji yang baik untuk ditanam atau dijadikan benih adalah biji yang benar-benar masak dan mempunyai ukuran benih yang konstan .benih yang bernas tentu akan memiliki bobot lebih tinggi dari pada benih kurang bernas. Benih yang mengalami kemunduran akan memiliki bobot lebih rendah dibandingkan benih yang bervigor tinggi.

\section{BAB 5. KESIMPULAN DAN SARAN}

\subsection{Kesimpulan}

Dari hasil penelitian dan pembahasan dapat ditarik kesimpulan sebagai berikut: a. Perlakuan konsentrasi Pupuk Organik Cair Biourine menunjukkan pengaruh yang berbeda tidak nyata pada semua parameter yang diamati.

b. Perlakuan varietas menunjukkan respon yang berbeda nyata terhadap parameter tinggi tanaman pada kacang hijau tidak bersertifikat (V1), jumlah cabang pada varietas Murai (V2), jumlah polong pada kacang hijau tidak bersertifikat (V1).

c. Tidak terdapat interaksi antara konsentrasi (K) Pupuk Organik Cair Biourine dan Varietas (V) pada semua parameter.

\subsection{Saran}

Berdasarkan hasil penelitian dan pembahasan yang telah dilakukan saran-saran yang dapat dikemukakan adalah sebagai berikut:

a. Perlu penggunaan varietas yang beragam tetapi memiliki umur tanaman dan hasil produksi yang sama sehingga dapat dilihat lebih jelas perbedaannya pada pertumbuhan dan hasil produksi

b. Agar penyerapan biourine dapat maksimal maka Perlu dilingkungan iklim yang mendukung

c. Perlu adanya penelitianlebih lanjut mengenai konsentrasi pupuk organik cair sehingga dapat menampakkan hasil

\section{DAFTAR PUSTAKA}

Andrianto, T.T. dan N. Indarto, 2004.Budidaya dan Analisis Usaha Tani: Kedelai, Kacang Hijau, Kacang Panjang. Yogyakarta: Kanisius.

Deptan.2008. Mengenal Plasma Nutfah Tanaman Pangan.Balai Penelitian dan Pengembangan Penelitian, Deptan.

Hasniawati, A. P. 2010. Pertumbuhan Kacang Hijau Nasional Masih Mini.http://investasi.kontan.co.id/v2/read/ 1272413106/35238/PertumbuhanProduksi-Kacang-Hijau-Nasional-MasihMini- [ 17 Agustus 2010].

Hakim, MA. 2009. Asupan Nitrogen Dan Pupuk Organik Cair Terhadap Hasil Dan Kadar Vitamin C Kelopak Bunga Rosella (Hisbiscus sabdariffa L.) Skripsi. Universitas Sebelas Maret Surakarta. 
http://digilih.uns.sac.id//abstrak.pdf.php?d id=16039[21 September 2012]]

Khairani, L. 2008. Respon Pertumbuhan dan Produksi Kacang Hijau Pada Beberapa Komposisi Lumpur Kering Domestik. Skripsi.

http://repository.usu.ac.id/bitstream/123456 789/7598/1/09E0025.pdf.[7 April 2011].

Lakitan, B. 1993.Dasar-Dasar Fisiologi Tumbuhan. Jakarta: Raja Grafindo Persada.

Lingga, M. Dan Marsono. 2013. Petunjuk Penggunaan Pupuk . Bogor: Penebar Swadaya

Mardalena.2007. Respon Pertumbuhan dan Produksi Tanaman Mentimun Terhadap Urine Sapi yang Telah Mengalami Perbedaan Lama Fermentasi. Laporan Tugas Akhir. Fakultas Pertanian, Universitas Sumatera Utara, Medan. Medan. (tidak dipublikasikan)

Marsono dan P. Sigit. 2001. Pupuk Akar, Jenis, dan Aplikasi. Jakarta: Penebar Swadaya.

Marzuki, H.A. dan H.S. Soeprapto, 2004.Bertanam Kacang Hijau. Jakarta: Penebar Swadaya.

Mugnisjah, W.Q. dan A. Setiawan, 1995.Produksi Benih. Jakarta: Bumi Aksara.
Purwono dan R. Hartono, 2005.Kacang Hijau. Jakarta: Penebar Swadaya.

Pusat Penelitian dan Pengembangan Tanaman Pangan. 2005. Varietas Unggul Kacang Hijau. Bogor.

Rukmana, R. 1997. Kacang Hijau Budidaya dan Pasca Panen. Yogyakarta: Kanisisus

Soemaatmadja, S. 1993. Sumber Daya Nabati Asia Tenggara I. Editor maesan, L. J. G. V. Jakarta: Grafindo PustakaUtama.

Soeprapto, H.S. 1993. Bertanam Kacang Hijau. Jakarta: Penebar Swadaya.

Sugiyarto, 2009, Optimasi Proses Fermentasi Urine Sapi pada Pembuatan Pupuk Organik Cair. Laporan Karyallmiah, Lab. Ilmu Tanah, Politeknik Negeri Jember. Jember. (tidak dipublikasikan)

Sutedjo, M.M. 2008. Pupuk dan Cara Pemupukan. Jakarta: Rineka Cipta.

Sutopo, L. 1993. Teknologi Benih. Jakarta: Raja Grafindo Persada.

Zulkarnain, 2009. Dasar- Dasar Hortikultura. Jakarta: Bumi Aksara. 